\title{
Allianties in de Nederlandse financiële sector: doelen, vormen, trends
}

\author{
Pieter Koene, Martijn Ars en Ard-Pieter de Man
}

\begin{abstract}
SAMENVATTING In vrijwel alle sectoren hebben ondernemingen sinds eind jaren '90 allianties opgezet. De financiële sector vormde hierop een uitzondering. Nederlandse banken en verzekeraars zijn recentelijk echter steeds meer allianties gaan opzetten. Het alliantiebeleid verschilt daarbij enigszins, afhankelijk van de door ondernemingen gevolgde strategie. De scherpe toename van het aantal allianties toont dat de samenwerkingstrend ook in de financiële sector sterk opkomt.
\end{abstract}

\section{Inleiding}

In vele sectoren hebben ondernemingen allianties ontdekt als geschikte organisatievorm voor de moderne economie. Steeds meer raken ondernemingen met elkaar verweven in samenwerkingsstructuren, die leiden tot complexe netwerken (De Man, 2006). Niet langer geven op zichzelf staande ondernemingen de toon aan in de economie. In plaats daarvan wordt concurrentievoordeel bereikt door samenwerking tussen ondernemingen. De financiële sector was één van de weinige sectoren waar alliantievorming nog niet op grote schaal plaatsvond. In de IT- en biotechsector begon de grote groei in het aantal allianties midden jaren negentig (De Man en Duysters, 2007). Data uit die tijd suggereren dat de financiële sector meer gericht was op fusie en overname dan op allianties (De Boer et al., 2004). Dat is de afgelopen jaren veranderd. Nederlandse financiële instellingen als Rabobank, ING, Achmea en Interpolis zijn de afgelopen jaren vele allianties aangegaan. Zowel in Nederland als daarbuiten hebben ze samenwerkings-

Prof. dr. A..P. de Man is werkzaam bij Atos Consulting en de Vrije Universiteit Amsterdam. Drs. P.J. Koene en Ir. C.M.F. Ars zijn verbonden aan PricewaterhouseCoopers. partners gevonden. De aard en omvang van deze belangstelling voor samenwerking wordt in dit artikel onderzocht. Wat drijft de banken en verzekeraars naar deze organisatievorm? Welke doelen streven ze na en welke middelen gebruiken ze? Allianties worden daarbij gedefinieerd als private samenwerkingsverbanden tussen onafhankelijke organisaties, gericht op het bereiken van een gezamenlijk doel, waarbij gezamenlijke besluitvorming plaatsvindt en gezamenlijke risico's, kosten en baten ontstaan (De Man, 2006). Voorbeelden zijn contractuele allianties, joint ventures, minderheidsdeelnemingen en complexe outsourcingsdeals.

De focus van bestaand onderzoek naar allianties in de financiële sector is beperkt. Er is onderzoek gedaan naar de structuur van allianties tussen banken en verzekeraars (Korhonen en Voutilainen, 2006), internationale consortia (Jacobsen en Tschoegl, 1999), motieven en opbrengsten van allianties in de financiële dienstverlening (Andersen Consulting, 1997), waardecreatie door allianties (Gleason et al., 2003) en de samenstelling van standaardiseringsconsortia rondom mobiele betalingen (Lim, 2006). Onderzoek onder managers door PricewaterhouseCoopers geeft aan dat er in de financiële sector wel veel belangstelling is voor de mogelijkheden van allianties (PricewaterhouseCoopers en Economist Intelligence Unit, 2005). Veertig procent van de respondenten zei naast autonome groei, ook groei door middel van allianties na te streven. Het percentage dat gebruik wil maken van fusies en overnames ligt significant lager (28\%). In 2003 lagen de verhoudingen nog anders. Toen gaf 42 procent van diezelfde respondenten aan te willen groeien door fusies en overnames en gaf slechts 21 procent te kennen te willen groeien door allianties (PricewaterhouseCoopers en Economist Intelligence Unit, 2003). Grootschalig onderzoek dat in kaart brengt hoe omvangrijk de trend nu werkelijk is, is echter schaars. Een gedetailleerder beeld over de vormen, doelen en alliantiestra- 
tegieën ontbreekt. Ook is er geen zicht op wat er in Nederland op dit vlak gebeurt.

Hieronder worden eerst de trends besproken die de ontwikkeling naar meer allianties aanjagen. Vervolgens wordt getoond dat de alliantieactiviteit van Nederlandse financiële instellingen snel groeit. De doelen en vormen van deze samenwerkingsverbanden worden geanalyseerd. Daarna wordt aandacht besteed aan verschillen in alliantiestrategieën van banken en verzekeraars. Ten slotte wordt aangegeven wat de managementimplicaties zijn.

\section{Omgevingstrends}

Allianties in de financiële sector zijn niet een compleet nieuw verschijnsel. Ook in de jaren zeventig werden allianties in de financiële sector aangegaan (Jacobsen en Tschoegl, 1999). De schaal was echter beperkt en de allianties waren defensief van aard. Zij waren bijvoorbeeld nodig omdat het wettelijk niet mogelijk was in een ander land te opereren. Een vijftal factoren verklaart de groeiende interesse van Nederlandse financiële instellingen voor allianties. Ten eerste is de Nederlandse markt volwassen. De bestaande markt is verdeeld. De gevestigde spelers richten zich op het behouden van de huidige klantenkring. Groei moet dus elders worden gezocht door allianties in het buitenland of door met partners nieuwe diensten aan te bieden. Fusie en overname is ook mogelijk (zie ABN Amro), zij het dat het aantal fusies klein zal blijven omdat het aantal spelers in Nederland klein is. De tweede aanjager van alliantievorming is toenemende internationalisering. Allianties kunnen belangrijk zijn in de internationale strategie van banken en verzekeraars. Vooral in economische groeimarkten in Azië en Latijns-Amerika. In China is de alliantie zelfs noodgedwongen de vereiste vorm voor verzekeraars, omdat buitenlandse partijen daar niet meer dan 30 procent van de aandelen mogen bezitten van Chinese ondernemingen (Reuer, 1999).

Een derde trend is Europese regelgeving (Flier et al., 2002). Op de Europese markt zorgt de harmonisatie van regelgeving ervoor dat banken en verzekeraars gemakkelijker kunnen toetreden tot nieuwe geografische gebieden. Verwacht wordt dat de harmonisatie van regelgeving zich verder gaat doorzetten naar steeds meer nieuwe gebieden. Deze trend hangt sterk samen met de trend van internationalisering. Overigens kan deze trend ook leiden tot meer fusies. De vierde aanjager van alliantievorming is technologie (Lim, 2006). Technologische ontwikkelingen in de informatietechnologie bevorderen het proces van internationalisering. Er kan met behulp van nieuwe informatie- en communicatietechnologie op afstand worden gewerkt en gecommuniceerd met klanten. Nog belangrijker voor alliantievorming is echter de rol die technologie speelt bij het ontwikkelen van standaarden voor betalingsverkeer en de rol van IT in het primaire proces van de bank en de verzekeringsmaatschappij. Het is voor de financiële instellingen niet mogelijk om alle ontwikkelingen op IT-gebied zelf bij te houden. Samenwerking met andere ondernemingen is het logische gevolg.

De vijfde trend ligt bij de klant. De Nederlandse klant wil steeds vaker een volledig financieel pakket aan producten afnemen, terwijl banken en verzekeraars zich richten op hun kerncompetenties. Door allianties met gespecialiseerde partners kunnen banken en verzekeraars deze twee zaken tegelijk realiseren. Een bank kan door samenwerking met een verzekeringsmaatschappij ook verzekeringen aanbieden.

Bovenstaande ontwikkelingen maken het logisch dat banken en verzekeraars zich meer gaan richten op allianties. Soms uit noodzaak, maar ook omdat marktkansen beter en sneller kunnen worden benut door allianties.

\section{Onderzoeksopzet}

Om het effect van de bovenstaande trends op alliantievorming in Nederland te onderzoeken is een onderzoek uitgevoerd naar de alliantiestrategieën van de belangrijkste Nederlandse banken en verzekeraars. De doelstelling van het onderzoek is om vast te stellen: - of allianties daadwerkelijk een trend zijn in de financiële sector;

- voor welke doelstelling allianties worden toegepast in de financiële sector;

- hoe banken en verzekeraars hun allianties structureren;

- met welk type partners allianties worden aangegaan. Het onderzoek heeft zich gericht op de allianties van ABN Amro, ING, Rabobank, Fortis, SNSReaal, Achmea, Aegon en Delta Lloyd. In het onderzoek is het aantal alliantieaankondigingen van deze partijen geteld over de periode 1996 tot 2005. Alliantieaankondigingen zijn verzameld via de artikelendatabase van het Financieele Dagblad en de persberichten van de Nederlandse banken en verzekeraars. Per alliantie zijn de volgende variabelen in kaart gebracht: opstartdatum van de alliantie, doelstelling, de alliantievorm, het aantal partners per alliantie, nationaliteit van de alliantiepartner en de sector waarin de alliantiepartner actief is.

Met betrekking tot de doelstelling van de alliantie is de classificatie van alliantiedoelstellingen van De Man et al. (1999) gebruikt. Een beperktere set van motieven 
zou bruikbaar kunnen zijn (Glaister en Buckley, 1996), maar hier is gekozen voor een breder scala, omdat deze studie vooral inventarisatie tot doel heeft. Een alliantie heeft tenminste één van de onderstaande doelstellingen:

- toegang creëren tot nieuwe geografische markten;

- toegang verkrijgen tot nieuwe competenties;

- bedienen van specifieke wensen van de klant;

- kostenreductie;

- risicospreiding;

- ontwikkelen van een nieuwe technologische standaard. Met betrekking tot het meten van de alliantievorm is in het onderzoek onderscheid gemaakt tussen equity en non-equity-allianties. Equity-allianties zijn partnerships waarbij twee ondernemingen een aandeelhoudersrelatie aangaan. Voorbeelden zijn joint ventures, waarbij twee of meer ondernemingen deelnemen in het kapitaal van een nieuwe onderneming, en minderheidsdeelnemingen. Non-equity-allianties zijn samenwerkingsverbanden waarbij de partners contractuele afspraken maken over inbreng, opbrengstenverdeling en coördinatie van de samenwerking. Hier zijn vele vormen mogelijk. In de categorisering van non-equity-allianties zijn consortia en outsourcingscontracten apart geteld.

Voor het meten van het aantal alliantiepartners is nagegaan of de samenwerking bilateraal was of een multi-partner samenwerking. Verder is in navolging van Gleason et al. (2003) per alliantiepartner bekeken of het een Nederlandse of buitenlandse onderneming was en of de alliantie intersectorale (bank of verzekeraar werkt samen met een onderneming uit een andere sector) of intrasectorale samenwerking (de bank of verzekeraar werkt samen met een andere bank of verzekeraar) betrof.

Elke variabele is gemeten aan de hand van een nominale score ( 0 of 1$)$. Er zijn 320 persberichten met alliantieaankondigingen verzameld. Op basis van de persberichten zijn de alliantievariabelen door de drie auteurs afzonderlijk gescoord. Afwijkingen op scores zijn bediscussieerd en een beperkt aantal scores is aangepast. Er zijn 19 persberichten verwijderd omdat zij onvoldoende informatie bevatten om de alliantie goed te kunnen scoren op alle variabelen. De analyse is dus uiteindelijk gebaseerd op 301 aangekondigde allianties tussen 1996 en 2005.

\section{Allianties in de Nederlandse financiële sector}

De onderzoeksresultaten laten zien dat het aantal alliantieaankondigingen door Nederlandse banken en verzekeraars sterk is gegroeid in de afgelopen tien jaar. In 1996 en 1997 zetten de grootste acht
Nederlandse banken en verzekeraars samen nog geen 20 allianties op, maar in 2005 is dat aantal gestegen naar bijna 80. Vooral in 2004 en 2005 is er een stijging te zien in het aantal alliantieaankondigingen (figuur 1). ING (60) en ABN Amro (50) hebben de meeste allianties opgezet tussen 1996 en 2005. Delta Lloyd (21), Aegon (27) en SNSReaal (27) hebben zich in aantallen minder gericht op allianties, maar zijn ook kleinere partijen. In het bijzonder bij ING, Fortis en SNSReaal is de groei in het aantal allianties de afgelopen paar jaar sterk geweest. Bij de andere partijen is de groei ook aanwezig, maar minder sterk. Allianties lijken dus inderdaad een steeds belangrijker instrument te worden voor banken en verzekeraars.

Figuur 1 Alliantieaankondigingen in de financiële sector

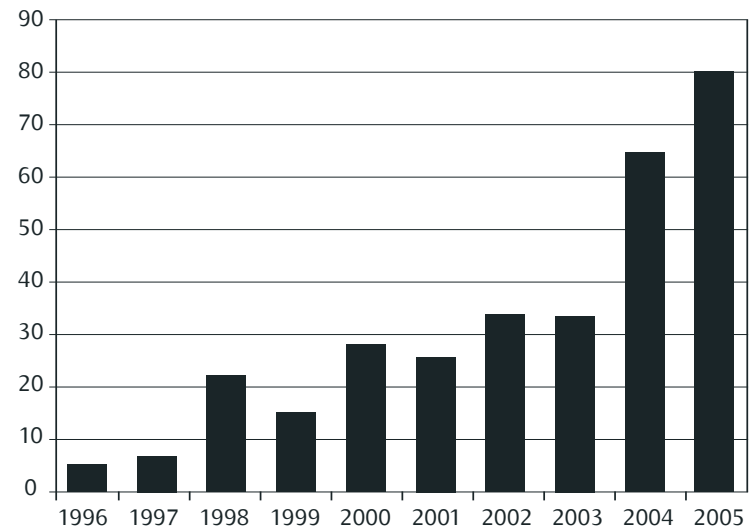

De belangrijkste alliantiedoelstelling van Nederlandse financiële instellingen is het verkrijgen van toegang tot nieuwe competenties (zie figuur 2). Hierbij gaat het om toegang tot kennis over producten of processen die een bank of verzekeraar zelf niet bezit. Een voorbeeld is de strategische samenwerking tussen ABN Amro en Delta Lloyd. ABN Amro heeft zelf geen verzekeringstak, maar werkt hiervoor samen in een joint venture met Delta Lloyd. Op deze manier kan ABN Amro haar All-finanz concept in de markt handhaven. Delta Lloyd krijgt op zijn beurt met de samenwerking toegang tot een grote nieuwe klantengroep. Ook voor e-channeling van financiële producten maken banken gebruik van specialistische partners. Rabobank is samen met Logica CMG en Talpa een TV-kanaal aan het ontwikkelen voor financiële dienstverlening.

De tweede doelstelling is toegang tot nieuwe geografische markten. De afgelopen twee jaar hebben vrijwel alle banken en verzekeraars allianties opgezet in 
landen als India, China en Korea op het gebied van levensverzekeringen, pensioenproducten en vermogensbeheer. De alliantie van ING met Vysya in India is een recent voorbeeld. De door ING, Fortis en Aegon in China, India, Japan en Korea opgezette joint ventures vergroten hun netwerk door samenwerking en krijgen van de overheden steeds meer licenties om hun producten in nieuwe provincies af te zetten.

De derde doelstelling van allianties betreft de zoektocht van veel banken en verzekeraars naar alternatieve retailkanalen met een focus op een specifieke klantengroep in Nederland. Verzekeraars zijn allianties aangegaan met onder meer supermarkten en pompstations om spaarregelingen, schade- en reisverzekeringen te verkopen. Ook op het gebied van zorgverzekeringen werken verzekeraars samen met gespecialiseerde partijen om beter bepaalde klantengroepen te bedienen. Achmea werkt samen met Philips om zijn verzekerde hartpatiënten met innovatieve meetapparatuur thuiszorg te kunnen aanbieden.

De vierde doelstelling die banken en verzekeraars hebben om allianties aan te gaan is om kostenefficiëntie te realiseren. Een voorbeeld is verzekeraar Achmea die een samenwerkingsverband met leaseen autoschadeherstelbedrijf Athlon is aangegaan voor de inkoop van auto-onderdelen. Bij de start hebben zich hier 250 herstelbedrijven bij aangesloten. Door gezamenlijke inkoop kunnen ze onderdelen goedkoper aanschaffen. Achmea kan dit voordeel doorrekenen in een premiekorting voor de klant. Kostenreductie vindt bij bijna iedere bank en verzekeraar ook plaats door uitbesteding van de ITsystemen. Een recent voorbeeld is de samenwerking tussen $A B N$ Amro en een conglomeraat van ITbedrijven onder leiding van IBM.

De vijfde doelstelling waarvoor allianties worden gebruikt in de financiële sector is het delen van hoge investeringsrisico's. Zo hebben ING en het Portugese Sonae Sierra in 2005 een joint venture opgezet voor het financieren van de investering in een winkelcentrum. Verder heeft Bouwfonds, de voormalige dochter van $A B N$ Amro, samengewerkt met ING in een consortium voor de ontwikkeling van een Duits bedrijvenpark.

Ten slotte werken banken en verzekeraars samen om nieuwe technologische standaarden te ontwikkelen. Zo hebben Nationale-Nederlanden en Aegon in 2004 hun softwareontwikkeling voor assurantietussenpersonen bij elkaar gevoegd in de joint venture Amedia. Een ander voorbeeld van een alliantie om een nieuwe standaard te ontwikkelen is Ideal. Dit is een nieuwe Internet betaalstandaard die is ontwikkeld door Rabobank, ING en ABN Amro.

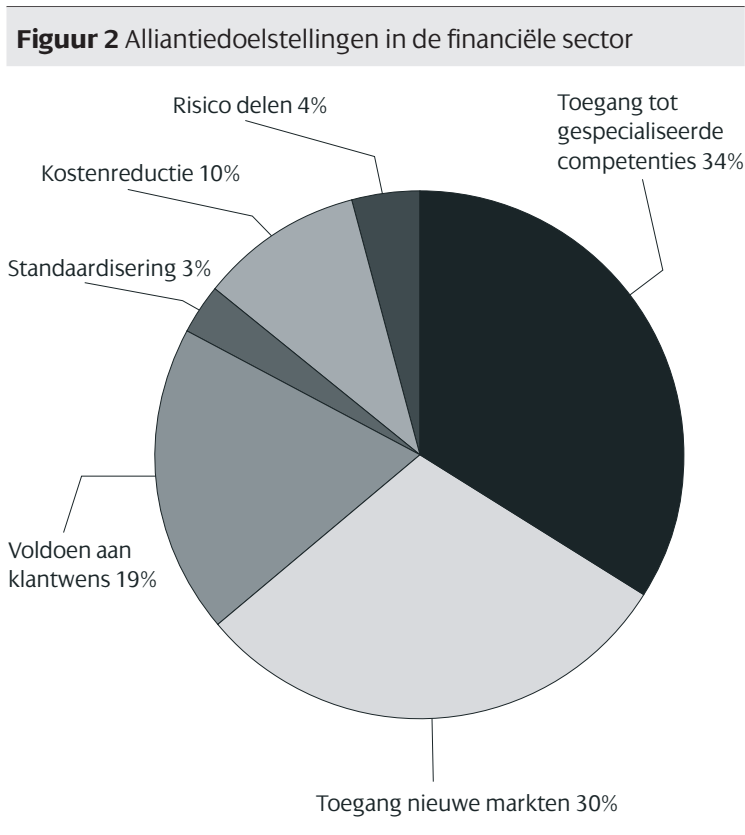

Ten aanzien van de structuur van allianties valt op dat het percentage equity-allianties hoog is in de financiële sector. Het aandeel equity-allianties over alle sectoren heen is in de loop van de tijd gedaald naar 10 procent (Duysters et al., 1999). De verhoudingen in de financiële sector liggen anders. 38 procent van de allianties zijn equity-allianties tegenover 62 procent non-equity-allianties. Figuur 3 laat zien dat het aandeel equity-allianties over de jaren afneemt en dat het de laatste drie jaar schommelt tussen de 20 en 30 procent. Wellicht dat banken en verzekeraars blijven kiezen voor het opzetten van joint ventures omdat ze daarin meer ervaring hebben (Pennings en Harianto, 1992). Het hoge aantal equity-allianties kan ook verklaard worden doordat banken en verzekeraars nog een hoge mate van control willen uitoefenen op alliantiepartners. Bijvoorbeeld omdat ze opportunistisch gedrag van de alliantiepartner vrezen. Gelet op het belang van een solide reputatie in de financiële sector, kan control meer van belang zijn (De Man, 2006). Aangezien aandeelhouderschap control verschaft (Das en Teng, 1998), doordat het een stem geeft in besluitvorming en toegang tot informatie, zouden banken en verzekeraars dus eerder voor equityallianties kunnen kiezen. Een laatste mogelijke verklaring voor het grote aantal equity-allianties is dat toegang tot nieuwe geografische groeimarkten een belangrijke doelstelling is voor banken en verzekeraars. Een equity-alliantie kan dan een voorloper zijn voor toekomstige overname, zoals bijvoorbeeld bij ABN Amro en Banco Antonveneta. 
Figuur 3 Equity versus non-equity-allianties

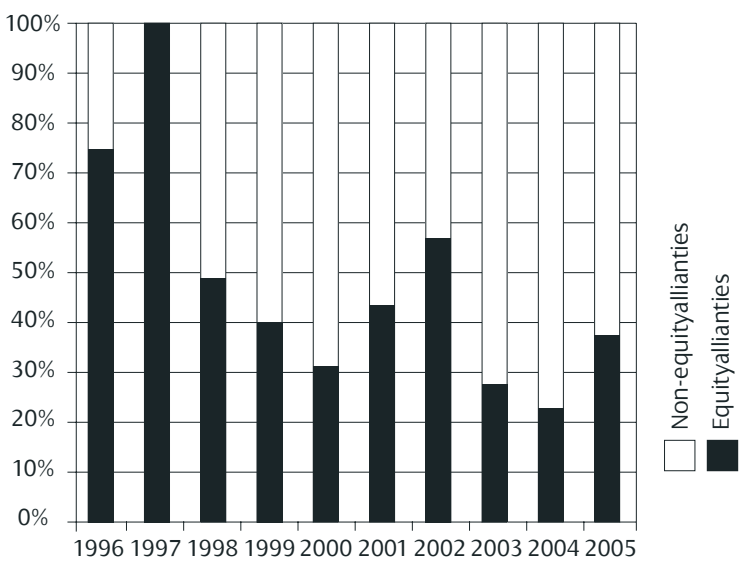

Banken en verzekeraars gaan vooral bilaterale relaties aan. De verhouding bilaterale relaties versus multipartner relaties is in de financiële sector 85-15 procent. Verder blijkt dat banken en verzekeraars zowel met buitenlandse partners samenwerken (53\%) als met Nederlandse partners (47\%). Dit wordt verklaard door het grote belang dat internationalisering inneemt in de alliantiedoelen van de Nederlandse financials. Met betrekking tot de sectorachtergrond van alliantiepartners geldt dat banken en verzekeraars vooral samenwerken met partners uit een andere sector (60\%). Het aantal allianties waarin wordt samengewerkt met een andere bank of verzekeraar is desalniettemin ook hoog (40\%).

\section{Typische alliantievormen}

Naast de hiervoor beschreven trends heeft dit onderzoek nog een andere interessante uitkomst. De doelstelling van een alliantie, de alliantiestructuur en de partnerkarakteristieken hangen vaak samen. Tabel 1 laat deze samenhang zien. Zij is samengesteld op basis van de two-step clustermethode. Dit is een statistische techniek die het mogelijk maakt om typische constellaties in data naar voren te brengen. De clusters zijn tot stand gekomen aan de hand van een categorisering op de verschillende alliantievormen van equity (minderheidsbelang/investering, joint venture) en non-equity (contractuele samenwerking, outsourcing contract, consortia). De analyse resulteert in vijf verschillende clusters. De tabel laat ook een aantal lege velden zien. Dit betekent dat binnen dit cluster meetvariabelen niet significant zijn.

Tabel 1 geeft de vorm van de alliantie weer, het aantal partners in de alliantie, de afkomst van de partners (binnenland of buitenland), de industrietak van de partners (komen alle partners uit de financiële sector of zijn er ook partners in de alliantie die uit een andere industrietak afkomstig zijn?) en de alliantiedoelstelling. Er zijn dan vijf clusters te onderscheiden. Het eerste cluster laat zien dat equity-allianties (joint ventures en minderheidsdeelnemingen) vooral worden gebruikt in bilaterale allianties, waarbij één van de partners van buitenlandse afkomst is, beide partners werkzaam zijn in de financiële dienstverlening en toegang tot nieuwe geografische markten het doel is. Een tweede cluster bestaat uit contractuele allianties, bilaterale relaties en Nederlandse partners uit andere sectoren. Allianties met deze kenmerken zijn gericht op het verkrijgen van nieuwe competenties en het bedienen van specifieke klantwensen. In het derde cluster komen ook contractuele allianties voor, maar vooral in de vorm van outsourcing. Outsourcing gaat samen met een partner uit een andere sector en heeft kostenreductie tot doel. Een vierde cluster wordt ook gekenmerkt door contractuele allianties, maar in dit geval met meer dan twee partners en gericht op de ontwikkeling van een technologische standaard. Standaardisering gebeurt dus voornamelijk met een groep van partners. Het laatste cluster bestaat ook uit

Tabel 1 Relatie tussen structuur, partnerkarakteristieken en motief

\begin{tabular}{|l|l|l|l|l|}
\hline \multirow{2}{*}{ Vorm } & \multirow{2}{*}{ Aantal partners } & Partnerkarakteristieken & \multirow{2}{*}{ Alliantiedoelstelling } \\
\cline { 4 - 5 } & Afkomst & Industrie & Toegang tot nieuwe geografische groeimarkten \\
\hline Equity & Bilateraal & Buitenlands & Partner uit financiële sector & Ton-equity \\
\cline { 4 - 5 } & Bilateraal & Nederlands & Partner uit andere sector & $\begin{array}{l}\text { Toegang tot nieuwe competenties } \\
\text { Bedienen specifieke klantwensen }\end{array}$ \\
\hline Non-equity, met name outsourcing & & & Partner uit andere sector & Kostenreductie \\
\hline Non-equity & Multipartner & & & Ontwikkelen nieuwe technologische standaard \\
\hline Non-equity met name consortia & & & Partner uit financiële sector & Verminderen investeringsrisico's \\
\hline
\end{tabular}


contractuele allianties, vooral consortia. Deze consortia bestaan alleen uit partners uit de financiële sector en zijn gericht op het verminderen van risico's.

Tabel 1 laat dus zien dat bepaalde doelen eerder worden gerealiseerd met bepaalde alliantievormen dan met andere. Er zijn typische constellaties te ontdekken van doel, vorm en type partner. De constellaties lijken ook logisch verklaarbaar. Outsourcing zal gewoonlijk plaatsvinden naar een niet-financiële instelling en is vaak gericht op kostenreductie. Veel van deze relaties zijn met IT-bedrijven. Voor standaardisering worden ook in andere sectoren vooral contractuele, multipartner allianties gebruikt. Met meer partners heeft een alliantie immers meer marktmacht en daardoor een grotere kans om de standaard geaccepteerd te krijgen. Niet alle allianties vallen echter binnen deze constellaties. Dat kan in een aantal gevallen inhouden dat er een foute keuze is gemaakt, maar er geldt ook dat maatwerk bij allianties altijd vereist is (De Man, 2006). Ondernemingen moeten zich dus ook weer niet te veel laten leiden door wat anderen doen. De tabel geeft hooguit een vuistregel voor de te kiezen combinatie van alliantiedoelen, vormen en partners.

\section{6}

\section{Verschillen tussen ondernemingen en sectoren}

In Nederland bestaan binnen de financiële sector grote verschillen in alliantiestrategieën van de acht partijen. Er bestaan met name verschillen tussen banken en verzekeraars. Deze verschillen zijn te verklaren uit de gevolgde businessstrategieën.

Het eerste verschil heeft betrekking op de alliantiedoelstellingen. ABN Amro, Aegon, Fortis, ING en Rabobank richten zich meer op toegang tot nieuwe geografische markten dan Achmea, Delta Lloyd en SNSReaal. Daar staat tegenover dat deze laatste drie zich met allianties weer meer richten op het inspelen op specifieke klantenwensen waarbij gebruik wordt gemaakt van specifieke aanvullende competenties van een alliantiepartner. Uitschieters in de analyse zijn Aegon, dat de helft van zijn allianties richt op het verkrijgen van toegang tot nieuwe markten, en SNSReaal dat de helft van de allianties richt op het inspelen op specifieke klantenwensen.

Ook met betrekking tot de structuur van de alliantie bestaan er verschillen tussen de banken en verzekeraars. De verhouding tussen equity en non-equity-allianties verschilt aanzienlijk. Fortis (52\%) en ING (51\%) hebben het grootste aandeel equity-allianties. Dit aandeel ligt bij Achmea (28\%) en Delta Lloyd (29\%) lager dan het sectorgemiddelde (38\%). Bij SNSReaal is het aandeel equity-allianties opvallend laag: 2 procent. Ondernemingen verschillen ook in hun keuzes voor samenwerken binnen de sector of daarbuiten en ten aanzien van hun keuze voor nationale of internationale alliantiepartners (zie figuur 4). Achmea, Delta Lloyd en SNSReaal werken vooral samen met nationale partners die werkzaam zijn in een andere dan de financiële sector. ABN Amro, Aegon en ING verkiezen het om meer samen te werken met internationale alliantiepartners die ook actief zijn in de financiële sector. Bij Rabobank en Fortis is dit onderscheid minder sterk. Zij werken zowel samen met internationale als nationale partners, actief in financiële en andere sectoren.

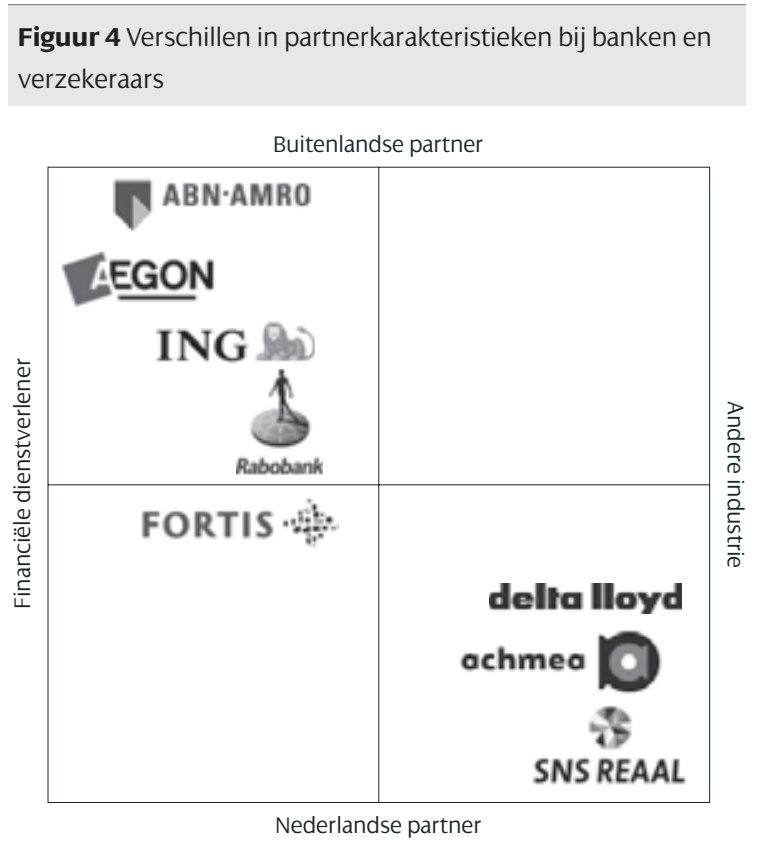

Deze verschillen laten zien dat ING en Aegon zich voornamelijk richten op schaalvergrotende activiteiten, zoals het afzetten van bestaande producten in nieuwe markten. Zij maken daarbij hoofdzakelijk gebruik van joint ventures en minderheidsdeelnemingen. In hun allianties werken zij samen met buitenlandse partners met een gelijksoortige dienstverlening. $\mathrm{Zij}$ trachten op die manier hun sterke positie in Nederland naar het buitenland over te brengen. Aegon heeft zijn strategie sinds 1983 gebaseerd op vier uitgangspunten: hoge omzet realiseren, internationale expansie, kostenefficiency realiseren en een betere positie in de markt innemen. Die uitgangspunten sluiten goed aan bij onze bevindingen, waarbij we hebben kunnen constateren dat Aegon veelal equity-allianties toepast om internationaal te blijven groeien. ING legt de nadruk in zijn strategie op een 
stijging van winst door middel van rendementsverbetering en winstgevende groei. Die winstgevende groei moet worden gerealiseerd in enerzijds direct banking en anderzijds op het gebied van pensioen- en levensverzekeringen in buitenlandse opkomende markten. Dat ING dus veel internationale groeiallianties heeft, past in dit beeld.

In tegenstelling tot ING en Aegon gebruiken SNSReaal, Delta Lloyd en Achmea allianties vooral om vernieuwende innovatieve diensten aan te bieden en voor productinnovaties. Daarbij wordt samengewerkt met partners uit andere sectoren die specifieke competenties bezitten waarover zij zelf niet beschikken. Het streven van SNSReaal om onderscheidend te zijn in de markt door zich te richten op specifieke klantengroepen is terug te vinden in het type alliantiepartners. De samenwerkingsverbanden met MSN, Free Record Shop, Mojo Concerts, Bart Foundation en Jetix zijn allemaal gericht op het bereiken van de jeugd. Omdat SNS in relatie tot de concurrentie een kleine speler is en daarnaast ook een focus heeft op uitsluitend de Nederlandse markt, zijn allianties bij uitstek geschikt het aanbod te differentiëren en via alternatieve distributiekanalen de klant te bereiken. Met andere woorden, allianties kunnen helpen bij het creëren van onderscheidend vermogen.

Wanneer de 301 allianties uit de analyse worden gescheiden in allianties gericht op bankgerelateerde activiteiten of verzekeringsgerelateerde activiteiten bestaan er ook enkele verschillen. Bij allianties van banken wordt er vaker samengewerkt met internationale alliantiepartners. Bij verzekeraars is dit tegenovergesteld. Verder valt op dat risicospreiding op investeringen en het ontwikkelen van nieuwe technologische standaarden vaker voorkomt bij banken dan bij verzekeringsmaatschappijen. Verzekeringsallianties richten zich meer op het vervullen van specifieke klantenwensen.

Op individeel bedrijfsniveau bleek dat sommige partijen (Aegon, ING, Fortis, ABN Amro) vaker equity-allianties gebruiken dan andere (SNSReaal en in mindere mate Delta Lloyd en Achmea). Dit onderscheid in alliantiestructuur is niet te herleiden naar de bank- of verzekeringsmarkt, maar naar individuele verschillen ten aanzien van alliantiedoelen.

Binnen de verzekeringsbranche zijn enkele verschillen te ontdekken in de manier waarop allianties worden toegepast, met name tussen de levenmarkt (levensverzekeringen en pensioenproducten) en de nietlevenmarkt (schadeverzekeringen, reisverzekeringen, zorgverzekeringen etc.). De verschillen in het gebruik van allianties op de levenmarkt en de niet-levenmarkt zijn veel groter dan de verschillen tussen de bank- en verzekeringsbranche. Verzekeraars op de levenmarkt sluiten vrijwel alleen equity-allianties af met buitenlandse partijen om producten af te zetten in nieuwe geografische groeimarkten. Op de niet-levenmarkt sluiten verzekeraars juist vooral contractuele allianties af met lokale partijen uit een andere sector, om zichzelf te onderscheiden. Dit verschil is verklaarbaar uit marktontwikkelingen. In nieuwe economische groeimarkten als India, China en Mexico groeit de leven- en pensioensector bijvoorbeeld met gemiddeld 15 tot 20 procent per jaar (PricewaterhouseCoopers, 2005). Allianties bieden de verzekeraars de mogelijkheid zich snel toegang tot deze groeimarkten te verschaffen. Op de schademarkt worden allianties gebruikt om nieuwe innovatieve diensten aan te bieden aan de Nederlandse consument. Hier zien we duidelijk minder hang naar buitenlandse expansie, maar worden allianties voornamelijk ingezet om op een creatieve wijze (nieuwe) klantengroepen te benaderen.

\section{Conclusies en implicaties}

De resultaten van het onderzoek tonen aan dat strategische allianties steeds belangrijker worden voor Nederlandse banken en verzekeraars. Het aantal alliantieaankondigingen in de financiële sector is in de periode tussen 1996 en 2005 snel gegroeid. Allianties worden voor verschillende doelstellingen opgezet, maar de belangrijkste redenen zijn toegang tot nieuwe geografische groeimarkten, toegang tot aanvullende competenties en het vervullen van wensen van specifieke klantengroepen. Het gebruik van equity-allianties ligt in de financiële sector relatief hoog in vergelijking met andere sectoren. Banken en verzekeraars sluiten vooral bilaterale samenwerkingsovereenkomsten. De acht partijen uit het onderzoek werken zowel samen met Nederlandse als internationale partners. Verschillen in alliantiestrategieën kunnen voor een belangrijk deel worden verklaard door het al dan niet hebben van een internationale focus en de verschillen in groeimogelijkheden in de respectievelijke markten. Het toenemende gebruik van allianties stelt de financiële sector voor een aantal uitdagingen. De eerste ligt op het vlak van alliantiemanagement. Bij ondernemingen in andere sectoren waar al langer en frequenter allianties worden aangegaan, zijn er inmiddels aparte afdelingen opgericht met alliantiemanagers die zich compleet richten op het managen van bestaande allianties en het opzetten van nieuwe allianties. Voorbeelden hiervan zijn te vinden bij Philips en KLM. Binnen deze alliantieafdelingen wordt ervaring en know-how over alliantiemanagement gecentraliseerd om het leereffect over allianties te verhogen. Dit draagt bij aan het succes van de alliantieportfolio 
(Kale, Dyer en Singh, 2002). Bij banken en verzekeraars bestaan deze afdelingen nog nauwelijks. Dat betekent dat zij een risico lopen dat het alliantiemanagement onvoldoende ontwikkeld is om allianties tot een succes te maken. De enigszins conservatieve alliantiestrategieën met veel equity-allianties kunnen ook een indicatie vormen van een onvoldoende ontwikkelde alliantievaardigheid. Ervaren ondernemingen kiezen minder vaak voor equity allianties.

Een tweede uitdaging die daarmee samenhangt, is dat banken en verzekeraars steeds meer afhankelijk worden van derde partijen. Aangezien reputaties in de financiële sector van groot belang zijn en de eisen van regelgevers ten aanzien van risico's steeds strenger worden, verdient de invoering van effectieve alliantiebesturing veel aandacht. Er zijn diverse manieren om grip te houden op samenwerking (De Man, 2006). Een juiste toepassing van de elementen van alliantiebestuur waarborgt enerzijds de groei en bloei van een alliantie en voorkomt anderzijds opportunistisch gedrag van alliantiepartners.

Ten slotte zullen banken en verzekeraars zich ook moeten bezighouden met de volgende stap op alliantiemanagementgebied: het portfolio- en netwerkmanagement. De kans dat zich conflicten tussen alliantiepartners gaan voordoen of dat informatie via partners doorlekt naar concurrenten wordt groter naarmate zij meer alliantiepartners hebben. Er zal dus meer aandacht moeten worden besteed aan de vraag wat de optimale portfolio aan allianties is en hoe die het best gemanaged kan worden.

De snelle groei van het aantal allianties laat zien dat de transformatie van organisaties van een model waarbij zij op zichzelf staan naar een model waarbij zij onderdeel zijn van een alliantienetwerk, de financiële sector heeft bereikt. In andere sectoren is gebleken dat dit een fundamentele omslag vraagt in het denken over strategie, organisatie en management. Indien de hierboven gesignaleerde ontwikkelingen doorzetten, zal de financiële sector zich erop moeten voorbereiden deze omslag te maken.

Nader onderzoek kan zich richten op een herhaling van deze studie op internationaal vlak en onderzoek naar de impact van verschillen in strategie op alliantiegedrag. Daarnaast kan het effect van alliantievorming op de prestaties van de onderneming in kaart worden gebracht. Ook de afweging fusie/overname versus alliantie verdient nadere studie, bijvoorbeeld door te onderzoeken of de middelen die ondernemingen hebben een rol spelen in deze keuze. Grotere banken kunnen wellicht sneller een overname doen dan kleinere.

\section{Literatuur}

Andersen Consulting (1997), Strategic Alliances in Financial Services, Special Report, September.

Boer, A. de, F.A.J. van den Bosch en H.W. Volberda (2004), Externe strategische vernieuwing van Europese financiele dienstverleners, Maandblad voor Accountancy en Bedrijfseconomie, jg. 78, no. 10, pp. 462-468.

Das, T.K., en D.S. Teng (1998), Between trust and control: developing confidence in partner cooperation in alliances, Academy of Management Review, vol. 23, no. 3, pp. 491-512.

Duysters, G.M., G. Kok en J. Vaandrager (1999), Crafting successful strategic technology partnerships, R\&D Management, vol. 29, no. 4, pp. 343-351.

Flier, B., F.A.J. van den Bosch en H.W. Volberda (2002), Het veranderende landschap in de Europese financiële sector, Maandblad voor Accountancy en Bedrijfseconomie, jg. 76, no. 3, pp. 103-112.

Glaister, K.W., en P.J. Buckley (1996), Strategic motives for international alliance formation, Journal of Management Studies, vol. 33, no. 3, pp. 301-332.

Gleason, K.C., I. Mathur en R.A. Wiggins (2003), Evidence on value creation in the financial services industries through the use of joint ventures and strategic alliances, The Financial Review, vol. 38, pp. 213-234.

Jacobsen, S.F., en A.E. Tschoegl (1999), The Norwegian banks in the Nordic consortia: A case of international strategic alliances in banking, Industrial and Corporate Change, vol. 8, no. 1, pp. 137-165.

Kale, P., J.H. Dyer, en H. Singh (2002), Alliance capability, stock market response, and long-term alliance success: the role of the alliance function, Strategic Management Journal, vol. 23, no. 8, pp. 747-767.

Korhonen, P., en R. Voutilainen (2006), Finding the most preferred alliance structure between banks and Insurance companies, European Journal of Operations Research, vol. 175, no. 2, pp. 1285-1299.

Lim, A. (2006), Power battles in ICT standards-setting process, proefschrift, Technische Universiteit Eindhoven, http://library.tue.nl/ csp/dare/LinkToRepository.csp? recordnumber $=615497$.

Man, A.P. de (2006), Alliantiebesturing: Samenwerking als precisieinstrument, Assen, Van Gorcum.

Man, A.P. de, en G.M. Duysters (2007), The second state of alliance management study, White Paper voor de Association of Strategic Alliance Professionals.

Man, A.P. de, H. van der Zee and D. Geurts (2000), Competing for Partners, Amsterdam, Prentice-Hall.

Pennings, J.M., en F. Harianto (1992), The diffusion of technological innovation in the commercial banking industry, Strategic Management Journal, vol. 13, no. 1, pp. 29-46.

PricewaterhouseCoopers (2005), FS Proposities 2005,: Nederlandse verzekeringsmarkt, Amsterdam, PricewaterhouseCoopers.

PricewaterhouseCoopers and Economist Intelligence Unit (2003), Focus on restructuring: the drivers shaping the financial services sector, London, PricewaterhouseCoopers.

PricewaterhouseCoopers and Economist Intelligence Unit (2005), Focus on growth: striking the right value balance within the financial services sector, London, PricewaterhouseCoopers.

Reuer, J. (1999), Collaborative strategy: the logic of alliances, Financial Times, Special Financial Times Mastering Strategy, september/oktober, pp. 34-37. 